\title{
Evapotranspiration and yield of irrigated chickpea
}

\author{
Piara Singh and S.M. Virmani \\ Resource Management Program, International Crops Research Institute for the Semi-Arid Tropics \\ (ICRISAT), ICRISAT Patancheru P.O., Andhra Pradesh 502324 (India)
}

(Received May 5, 1989; revision accepted February 21, 1990)

\begin{abstract}
Singh, P. and Virmani, S.M., 1990. Evapotranspiration and yield of irrigated chickpea. Agric. For. Meteorol., 52: 333-345.

Field experiments were conducted during the 1986 and 1987 post-rainy seasons to relate total above ground dry matter (TDM) and seed yields of chickpea (Cicer arietinum L. cv JG 74) with evapotranspiration (ET). The crop was subjected to various degrees of water stress by applying gradient irrigations during three growth phases: emergence to $50 \%$ flowering; $50 \%$ flowering to $50 \%$ beginning pod-fill; $50 \%$ beginning pod-fill to physiological maturity. Analysis of the 2-year pooled data showed that across seasons both total dry matter and seed yields were more strongly correlated with normalized ET $\left(R^{2}=0.92, P<0.01\right.$ for TDM, and $R^{2}=0.82, P<0.01$ for seed yield), defined as ratio of actual ET to saturation vapour pressure deficit of air, than with actual ET $\left(R^{2}=0.56, P<0.01\right.$ for TDM, and $R^{2}=0.40, P<0.01$ for seed yield). Partitioning of total normalized ET observed during the season into normalized ET observed during two or three growth phases of chickpea and regressing seed yield against them did not improve the predictability of models. It is concluded from this study that both total dry matter production and seed yield responses of chickpea to water management can be predicted if the normalized ET during the season is known.
\end{abstract}

\section{INTRODUCTION}

Most chickpea (Cicer arietinum L.) in the semi-arid tropical areas of India is grown as a winter crop on stored soil water from the preceding rainy season. It may receive little rainfall during the growing season in some areas or may be provided with supplemental irrigation to save the crop from drought. In addition to the variability in soil water availability, the chickpea crop is also subjected to high temperatures and high evaporative demand, especially in the central and southern parts of the country, leading to yield reductions (Sheldrake and Saxena, 1979). Because chickpea is generally grown in water

Submitted as Journal Article No. 895 by the International Crops Research Institute for the SemiArid Tropics (ICRISAT). 
limiting environments, its yields are reported to be highly correlated with evapotranspiration (ET) during the season (Singh and Bhushan, 1980; Singh and Das, 1987). But the water use efficiency (yield per unit of ET) has been reported to range from 5.2 to $35.2 \mathrm{~kg} \mathrm{ha}^{-1} \mathrm{~mm}^{-1}$ for above ground biomass and 1.1 to $15.7 \mathrm{~kg} \mathrm{ha}^{-1} \mathrm{~mm}^{-1}$ for seed yield (Sandhu et al., 1978; Singh and Bhushan, 1980; Keatinge and Cooper, 1983; Siddique and Sedgley, 1985; Sivakumar and Singh, 1987). These results on water use efficiency (WUE) are location, season, and management specific and, therefore, cannot be generalized for predicting crop yields based on ET.

When the crop is not suffering from nutritional deficiency, the factors which could influence the WUE for biomass production of a crop are the amount of soil evaporation relative to transpiration and the aridity of the environment. In addition to these factors the sensitivity of different growth phases of a crop to water deficits could also influence the WUE for seed yield. Using the theoretical basis for the relation between $\mathrm{CO}_{2}$ uptake and water loss as transpiration initially examined by Bierhuizen and Slatyer (1965), Tanner and Sinclair (1983) concluded that biomass production of a crop is strongly correlated with normalized transpiration (ratio of actual transpiration to the saturation vapour pressure deficit of air) as per the following relation.

$$
Y=k\left[T /\left(e^{*}-e\right)\right]
$$

where: $Y$ is the biomass yield, $T$ is transpiration; $e^{*}$ is the saturation vapour pressure at air temperature; $e$ is the actual vapour pressure at air temperature; $k$ is a crop-specific constant. Because soil evaporation and transpiration are difficult to separate and because they both are influenced by the saturation deficit of air $\left(e^{*}-e\right)$, it was hypothesized that total dry matter production and seed yield would also be strongly correlated with normalized ET (ratio of actual ET to the saturation deficit of air) across environments and seasons, and could thus be used to predict chickpea yields. Field experiments were conducted over the two seasons to test the hypotheses: (a) that normalized ET is a better predictor of total biomass and seed yield of chickpea than actual ET; (b) that if seed yield is regressed against normalized ET values for different growth phases of chickpea rather than total normalized ET, it shall further improve the predictability of models.

\section{MATERIALS AND METHODS}

\section{Site, experiments and management}

Experiments were conducted during the post-rainy seasons of 1986 and 1987 on a vertisol at the research farm of the International Crops Research Institute for the Semi-Arid Tropics (ICRISAT), located at Patancheru $\left(17^{\circ} 30^{\prime} \mathrm{N}\right.$; $78^{\circ} 16^{\prime} \mathrm{E}$; altitude $549 \mathrm{~m}$ ), Andhra Pradesh, India. The soil, treatments, and 
management of the 1986 experiment have been described in a previous paper (Singh and Sri Rama, 1989). Briefly, the 1986 experiment consisted of four irrigation treatments, which were: (1) gradient irrigation at all growth stages; (2) gradient irrigation from emergence to $50 \%$ flowering and uniform irrigation at other growth stages; (3) gradient irrigation at 50\% flowering to $50 \%$ beginning pod-fill and uniform irrigation at other growth stages; (4) gradient irrigation from $50 \%$ beginning pod-fill to physiological maturity and uniform irrigation at other growth stages. A line-source sprinkler irrigation system (Hanks et al., 1976) was used to impose gradients of irrigation, while uniform irrigations were given using perforated pipes. The experiment in the 1987 season was laid out in the same fashion as in 1986 and the irrigation treatments were also the same. However, there were no subtreatments in the 1987 season. Chickpea (cv JG 74) was sown on 28 October 1987 and emerged on 5 November. A plant population of 30 plants $\mathrm{m}^{-2}$ was maintained and the other crop management was the same as in 1986 . There were three replicates of treatments in both experiments. The method and timing of irrigations in various treatments were also the same as in 1986, however, the amounts of irrigation applied in a treatment differed between seasons because of the prevailing weather conditions.

\section{Soil water and $E T$}

To monitor changes in soil water content, neutron probe access tubes were installed in each plot at 3.6,6.8,10.0,13.2, and $16.4 \mathrm{~m}$ from the line-source in 1986 and at $1.8,4.8,7.8,11.4$, and $15.6 \mathrm{~m}$ in 1987. These five locations were designated as A, B, C, D, and E moisture regimes, respectively (Fig. 1). The remaining procedure of soil water monitoring and estimation of ET was the same as in the 1986 season (Singh and Sri Rama, 1989), except in the 1987 season when $240 \mathrm{~mm}$ of rain fell during the first 22 days after sowing causing excessive runoff, which interfered with the estimation of ET using the neutron probe data. ET during this wet period was estimated using the water balance model of Ritchie (1972) which required leaf area index, potential evapotranspiration, and the data on water holding characteristics of the soil as inputs to run the model.

\section{Saturation deficit of air}

To calculate saturation vapour pressure deficit of the air, wet- and dry-bulb temperatures were recorded very close the surface of the crop canopy in each main plot of one replication using aspirated thermocouple psychrometers installed at $\mathrm{A}, \mathrm{C}$, and $\mathrm{E}$ moisture regimes. The psychrometers were scanned 


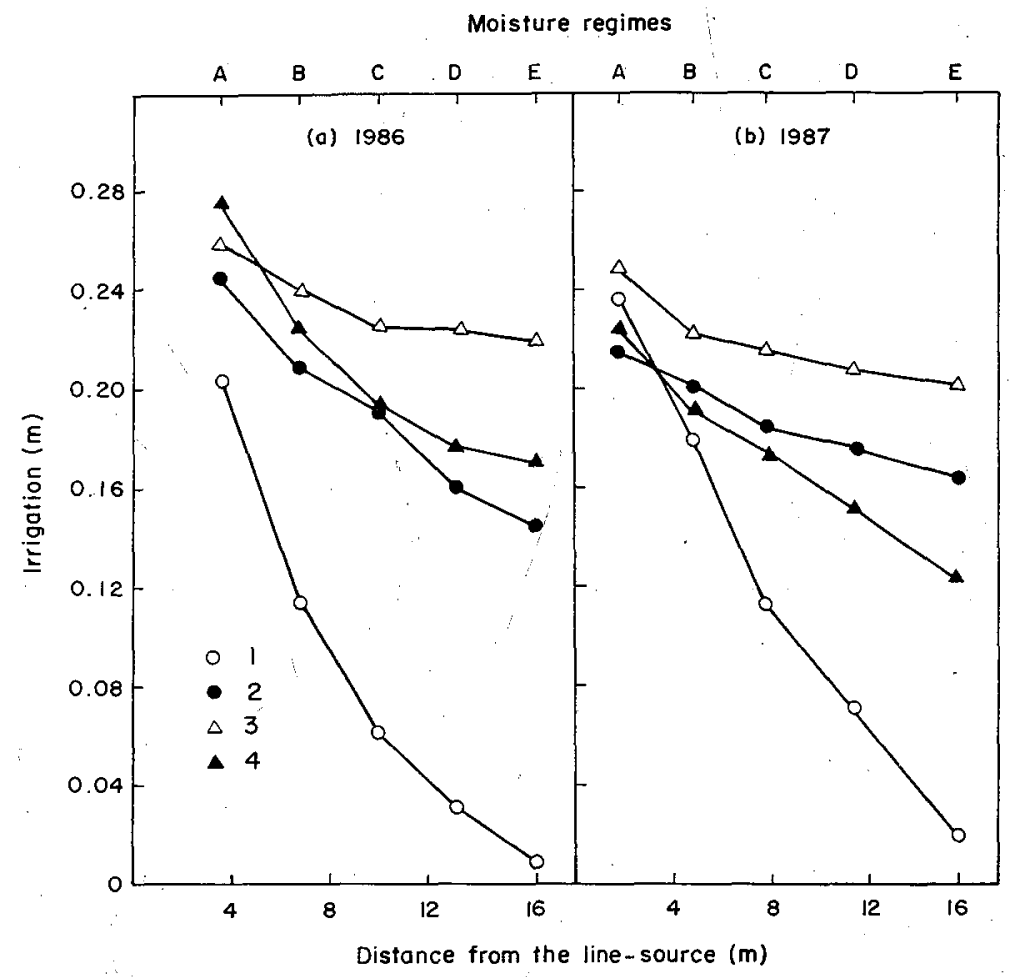

Fig. 1. Amounts of irrigation given to different treatments in the (a) 1986 and (b) 1987 seasons. For irrigation treatments 1 to 4 , see text.

hourly and the data were recorded on a micrologger (CR21X*, Campbell Scientific, Inc., UT, U.S.A.). The observations recorded between 12:00 and 14:00 $h$ were used in the analysis.

\section{Growth analysis and crop yields}

Plant samples were taken once a week from a $0.30 \mathrm{~m}^{2}$ area at $\mathrm{A}, \mathrm{C}$, and $\mathrm{E}$ moisture regimes in each treatment during both seasons. Plant components were separated and leaf area of each sample was determined using a leaf area meter (LI-COR, Inc., U.S.A.) and then dried at $60^{\circ} \mathrm{C}$ in an oven for a week and weighed to determine its dry weight. As the crop progressed towards maturity, some leaf-fall on the ground was observed in some treatments. These fallen leaves were collected and included in the sample to have an accurate estimate of total dry matter production.

*Mention of commercial products or companies does not imply their endorsement or recommendation by ICRISAT. 
The final harvests for crop yields were made from a $9 \mathrm{~m}^{2}$ area around each neutron probe tube on 24 February, 1986 and from a $15 \mathrm{~m}^{2}$ area around each tube on 15 February, 1987. The harvested material was oven dried at $60^{\circ} \mathrm{C}$ until it reached a constant weight. Total number of pods in each sample were counted and finally threshed to determine total seed number, seed weight, and total dry matter production.

\section{RESULTS AND DISCUSSION}

Total rainfall during November was greater in $1987(240 \mathrm{~mm})$ than in 1986 (36.8 $\mathrm{mm}$ ) (Table 1). This decreased both maximum and minimum temperatures during November and December 1987 resulting in a low mean saturation vapour pressure deficit of the air at the surface of the crop canopy during the period from emergence to $50 \%$ beginning pod-fill (Table 2 ). Rainfall during December, January, and February was negligible during both seasons. Open-pan evaporation and solar radiation per day was generally lower in 1987 than in 1986 (Table 1). The seasons did not differ in saturation deficit of air during the pod-filling period. Saturation deficit of air observed in the meteorological observatory was generally greater than that observed in the field (Table 2). Therefore field microclimatic data was used to relate plant growth with the environment.

There were no yield responses to the-different levels of plant population studied in 1986, so all data on plant and soil observations were averaged over subtreatments for further analysis. Total above ground dry matter at harvest

\section{TABLE 1}

Monthly mean values of various climatic elements during the 1986 and 1987 seasons as observed in the meteorological observatory about $500 \mathrm{~m}$ away from the experimental plot

\begin{tabular}{|c|c|c|c|c|c|c|}
\hline Month & Year & $\begin{array}{l}\text { Total rainfall } \\
\text { (mm) }\end{array}$ & $\begin{array}{l}\text { Open-pan } \\
\text { evaporation } \\
\left(\mathrm{mm} \mathrm{day}^{-1}\right)\end{array}$ & $\begin{array}{l}\text { Max. temp. } \\
\left({ }^{\circ} \mathrm{C}\right)\end{array}$ & $\begin{array}{l}\text { Min. temp. } \\
\left({ }^{\circ} \mathrm{C}\right)\end{array}$ & $\begin{array}{l}\text { Solar } \\
\text { radiation } \\
\left(\mathrm{MJ} \mathrm{m}^{-2} \mathrm{day}^{-1}\right)\end{array}$ \\
\hline Nov & $\begin{array}{l}1986 \\
1987\end{array}$ & $\begin{array}{r}36.8 \\
240.0\end{array}$ & $\begin{array}{l}4.8 \\
3.6\end{array}$ & $\begin{array}{l}29.9 \\
27.5\end{array}$ & $\begin{array}{l}17.2 \\
18.0\end{array}$ & $\begin{array}{l}16.1 \\
13.6\end{array}$ \\
\hline Dec & $\begin{array}{l}1986 \\
1987\end{array}$ & $\begin{array}{l}6.3 \\
0.8\end{array}$ & $\begin{array}{l}5.0 \\
3.8\end{array}$ & $\begin{array}{l}28.5 \\
26.9\end{array}$ & $\begin{array}{l}15.3 \\
14.2\end{array}$ & $\begin{array}{l}15.5 \\
15.1\end{array}$ \\
\hline Jan & $\begin{array}{l}1987 \\
1988\end{array}$ & $\begin{array}{l}4.4 \\
0.0\end{array}$ & $\begin{array}{l}5.1 \\
4.6\end{array}$ & $\begin{array}{l}28.6 \\
28.4\end{array}$ & $\begin{array}{l}15.0 \\
14.1\end{array}$ & $\begin{array}{l}17.1 \\
16.9\end{array}$ \\
\hline Feb & $\begin{array}{l}1987 \\
1988\end{array}$ & $\begin{array}{l}0.0 \\
4.0\end{array}$ & $\begin{array}{l}7.7 \\
6.1\end{array}$ & $\begin{array}{l}30.6 \\
32.0\end{array}$ & $\begin{array}{l}15.6 \\
17.4\end{array}$ & $\begin{array}{l}18.8 \\
17.5\end{array}$ \\
\hline
\end{tabular}


TABLE 2

Saturation vapour pressure deficit of the air (SD) close to the surface of the crop canopy and in the meteorological observatory during different crop growth periods of chickpea during the 1986 and 1987 seasons

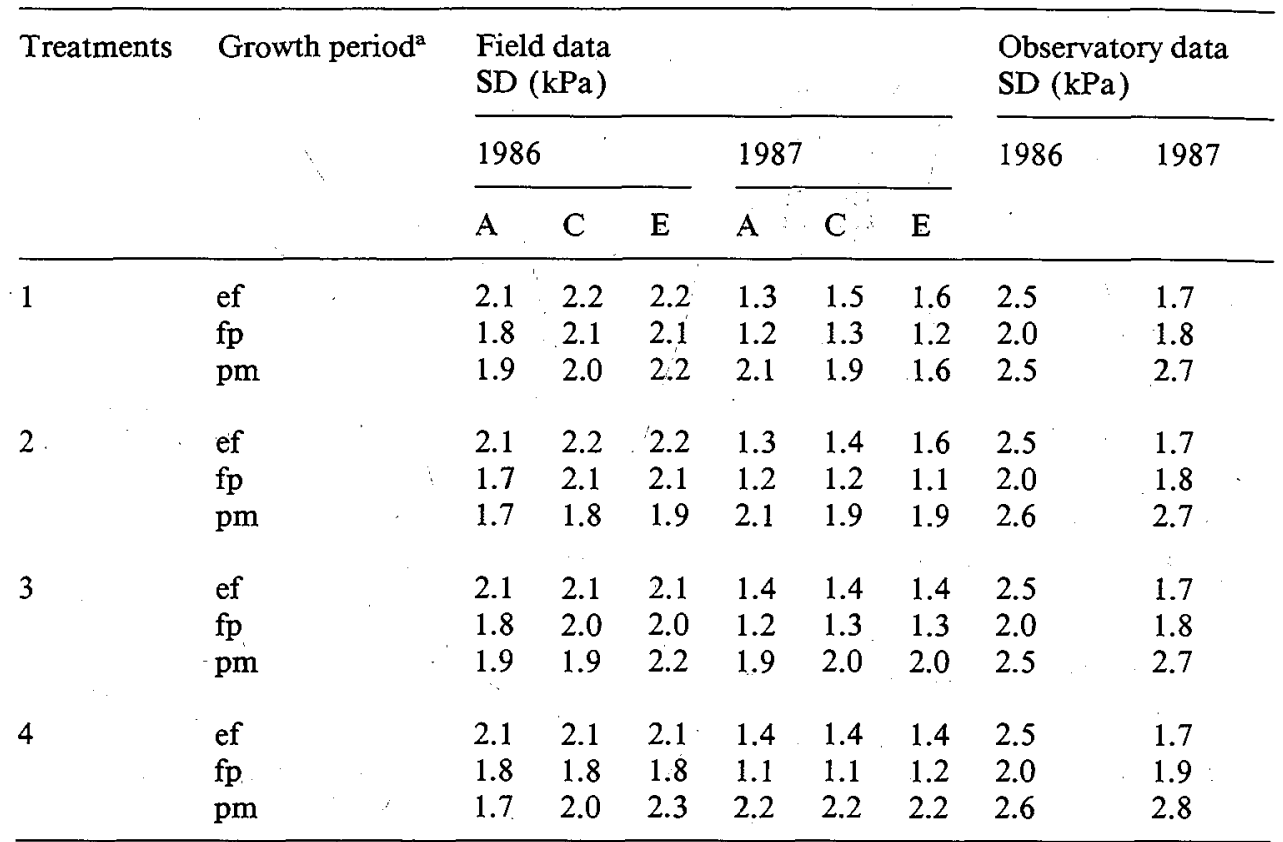

${ }^{a}$ Note: ef $=$ emergence to $50 \%$ flowering; $\mathrm{fp}=50 \%$ flowering to $50 \%$ beginning pod-fill; $\mathrm{pm}=50 \%$ beginning pod-fill to physiological maturity.

was significantly correlated with total ET during both seasons (Fig. 2). However, the WUE, which is often described as dry matter produced per unit of $\mathrm{ET}$, was greater in $1987\left(19.0 \mathrm{~kg} \mathrm{ha}^{-1} \mathrm{~mm}^{-1}\right)$ than in $1986\left(13.5 \mathrm{~kg} \mathrm{ha}^{-1}\right.$ $\mathrm{mm}^{-1}$ ). The lower WUE in 1986 than in 1987 could be attributed to the greater saturation vapour pressure deficit of the air during 1986 which caused greater water loss from the crop canopy relative to carbon dioxide intake (Bierhuizen and Slatyer, 1965; Tanner and Sinclair, 1983). When the data of the two seasons were pooled and the total dry matter (TDM) produced was regressed against normalized ET (ratio of actual ET to the saturation vapour pressure deficit of air), a single line could be fitted through the data indicating that normalized WUE (TDM per unit of normalized ET) was the same (31.3 $\mathrm{kg} \mathrm{kPa} \mathrm{ha}^{-1} \mathrm{~mm}^{-1}$ ) for both the low and high evaporative demand years.

To further assess the conservative nature of the normalized WUE of chickpea, data in the literature on WUE of chickpea was used to calculate normalized WUE for various locations in India, Australia and Syria. Mean satura- 

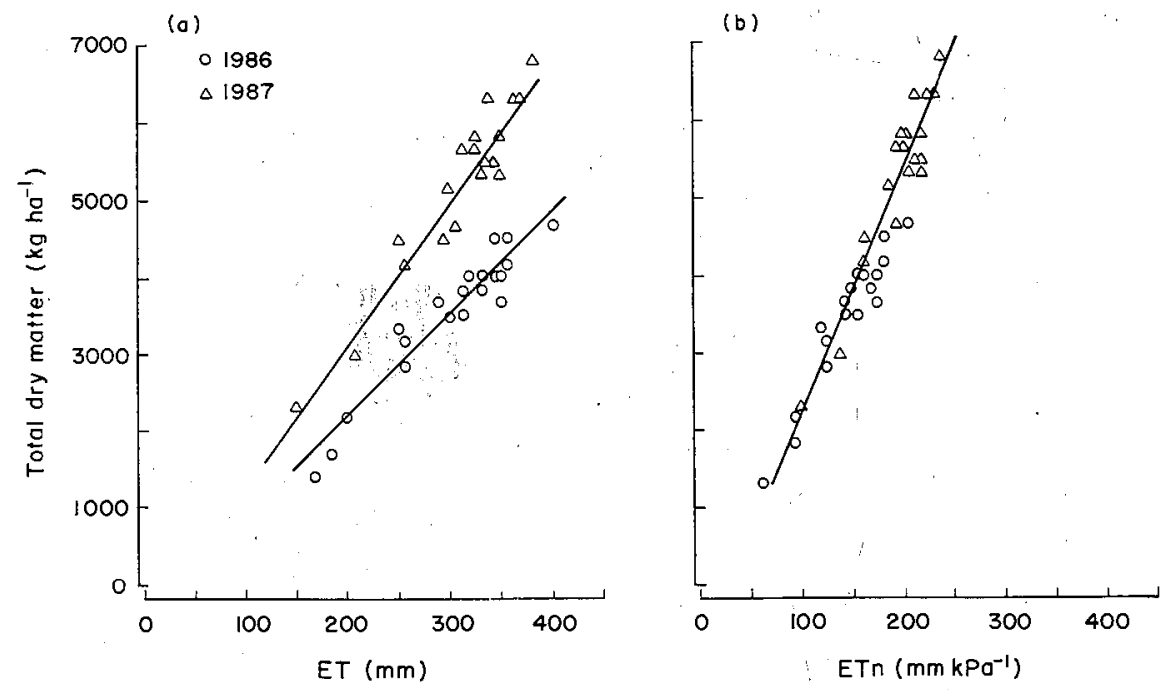

Fig. 2. Relation of chickpea total above ground dry matter production with (a) ET (for 1986: $Y=-520.8+13.5 X$, rse $=262.7, R^{2}=0.91, P<0.01$; for $1987: Y=-659.7+19 X$, rse $=343.7$, $R^{2}=0.91, P<0.01$; for pooled data: $Y=-837.2+17.1 X$, rse $\left.=865.3, R^{2}=0.56, P<0.01\right)$ and with (b) $\mathrm{ET}_{\mathrm{n}}\left(Y=-997.3+31.3 X\right.$, rse $\left.=362.0, R^{2}=0.92, P<0.01\right)$.

tion deficits during the chickpea growing season were estimated from the openpan evaporation values reported by various workers and by using a relation between mean monthly saturation deficit of the air and mean monthly openpan evaporation. This relationship was developed from data recorded at the meteorological observatory at the ICRISAT Center, Patancheru, India (Table 3). Normalized WUE was less variable between locations than actual WUE except for spring sown chickpea at three locations in Syria. Low values of normalized WUE for spring sown chickpea could be attributed to excessive soil evaporation during the spring season as reported by Keatinge and Cooper (1983). This analysis shows that under most conditions normalized WUE of chickpea is a conservative value.

Like total dry matter production, seed yield was also significantly correlated with total seasonal ET $\left(R^{2}=0.79, P<0.01\right.$ for 1986 and $R^{2}=0.82$, $P<0.01$ for 1987) (Fig. 3). WUE values for seed yield were $5.1 \mathrm{~kg} \mathrm{ha}^{-1} \mathrm{~mm}^{-1}$ for 1986 and $8.0 \mathrm{~kg} \mathrm{ha}^{-1} \mathrm{~mm}^{-1}$ for 1987 . Analysis of the 2-year pooled data show that seed yield was poorly correlated with seasonal ET $\left(R^{2}=0.40\right)$. But when seed yield was regressed against normalized ET $R^{2}$ improved to 0.82 , and $14.5 \mathrm{~kg} \mathrm{ha}^{-1}$ of seed was produced per mm of normalized ET. Similar responses of WUE to increased aridity of the environment have been reported in several other studies. For example, Singh et al. (1982) found that under controlled conditions WUE of chickpea decreased with increasing sat- 


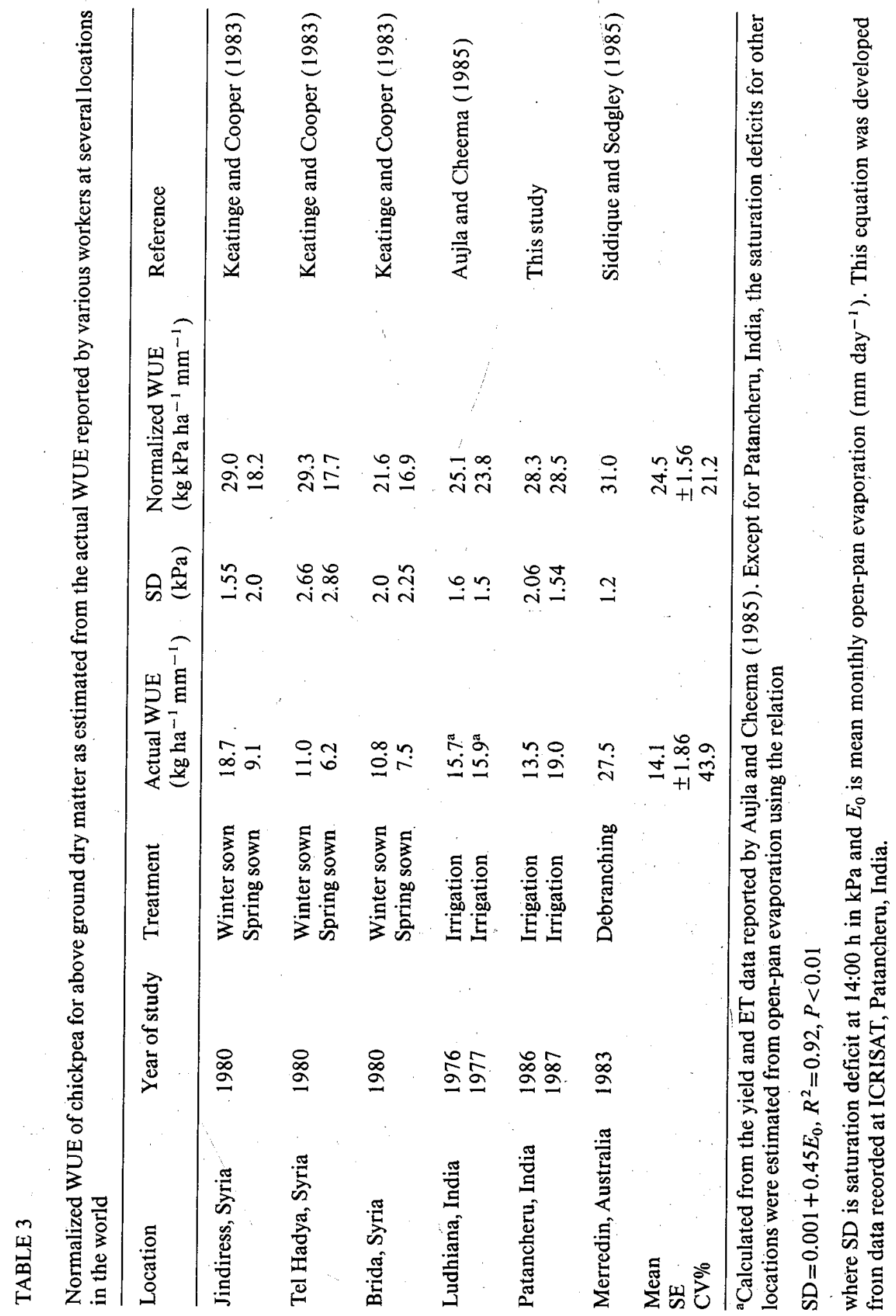



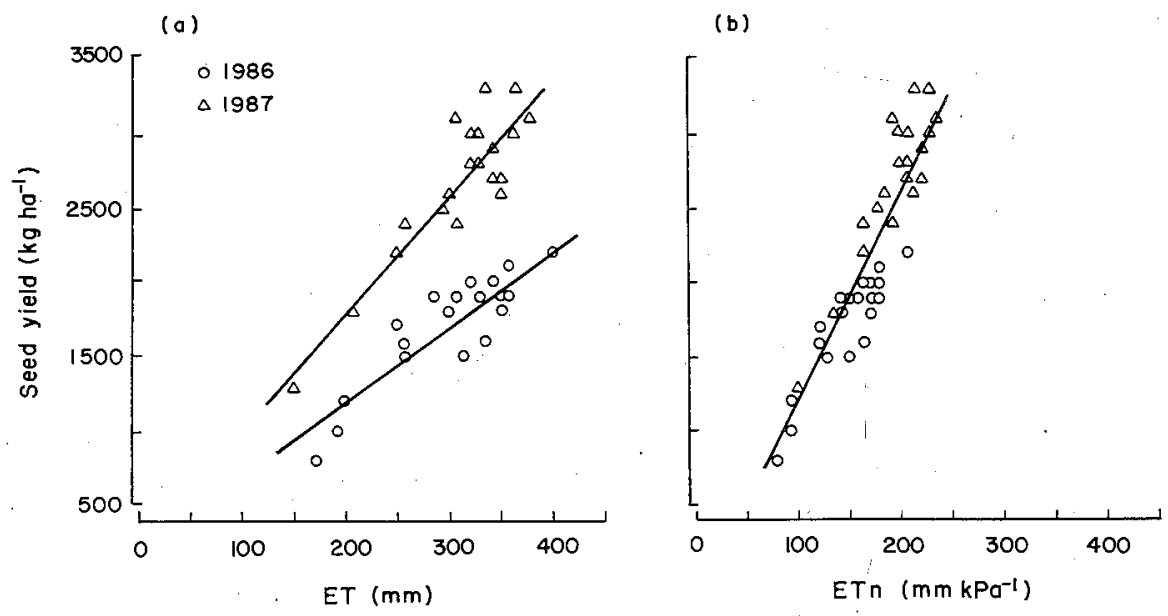

Fig. 3. Relation of chickpea seed yield with (a) ET (for 1986: $Y=166.7+5.1 X$, rse $=167.0$, $R^{2}=0.79, P<0.01$; for 1987: $Y=190.2+8.0 X$, rse $=212.6, R^{2}=0.82, P<0.01$; for pooled data: $Y=31.8+7.1 X$, rse $\left.=498.7, R^{2}=0.40, P<0.01\right)$ and with (b) $\mathrm{ET}_{\mathrm{n}}(Y=-298+14.5 X$, rse $=269.5, R^{2}=0.82, P<0.01$ ).

uration deficit of the air and temperature. They attributed this response to an increase in stomatal conductance for water loss with increased saturation deficit of the air. Similarly, Keatinge and Cooper (1983) reported greater WUE for both total above ground biomass and seed yield of Kabuli chickpea varieties in a less arid environment at Jindiress than at Tel Hadya and Breda in northern Syria. Singh and Bhushan (1980) reported WUE values for chickpea seed yield ranging from 9.0 to $15.0 \mathrm{~kg} \mathrm{ha}^{-1} \mathrm{~mm}^{-1}$ in north Indian conditions where temperatures and aridity of the environment during the chickpea growing season are generally lower than central and southern India. These results confirm that actual ET cannot be used for reliable estimates of chickpea total dry matter and seed yields in different environments and seasons. ET must be normalized with the saturation deficit of the air to improve their predictions.

Another factor which could influence the seed yield of chickpea is the varying sensitivity of its growth phases to water deficits. When seed yield of chickpea was regressed against normalized ET from emergence to the beginning of pod-fill and the beginning of pod-fill to physiological maturity, $R^{2}$ increased to 0.87 (Table 4). Further partitioning of normalized ET into the three growth phases, i.e. emergence to $50 \%$ flowering, $50 \%$ flowering to $50 \%$ beginning podfill, and $50 \%$ beginning pod-fill to physiological maturity, and regressing seed yield against them increased $R^{2}$ to 0.89 . Although $R^{2}$ increased because of partitioning of ET into different growth phases, the error mean square did not decrease significantly, indicating that partitioning of ET does not significantly improve the predictability of the models for seed yield. Thus the seed 


\section{TABLE 4}

Equations relating total dry matter (TDM) and seed yield (SYLD) of chickpea with evapotranspiration. Analysis done on 2 years pooled data

\begin{tabular}{lllll}
\hline $\begin{array}{l}\text { Equation } \\
\text { number }\end{array}$ & $N$ & Equation & $\begin{array}{l}\text { Adjusted } \\
R^{2}\end{array}$ & $\begin{array}{l}\text { Error mean } \\
\text { square }\end{array}$ \\
\hline & & Total dry matter & & \\
1 & 40 & TDM $=-837.2+17.1 \mathrm{ET}$ & 0.56 & $7.5 \times 10^{5} \mathrm{a}$ \\
2 & 40 & TDM $=-997.3+31.3 \mathrm{ET}_{\mathrm{n}}$ & 0.92 & $1.3 \times 10^{5} \mathrm{~b}$ \\
& & Seed yield & 0.40 & $2.5 \times 10^{5} \mathrm{a}$ \\
3 & 40 & SYLD $=31.8+7.1 \mathrm{ET}$ & 0.82 & $7.3 \times 10^{4} \mathrm{~b}$ \\
4 & 40 & SYLD $=-298.0+14.5 \mathrm{ET}_{\mathrm{n}}$ & 0.87 & $5.3 \times 10^{4} \mathrm{~b}$ \\
5 & 40 & SYLD $=-104.7+9.4\left(\mathrm{ET}_{\mathrm{n}}\right)_{\mathrm{ep}}+20.8\left(\mathrm{ET}_{\mathrm{n}}\right)_{\mathrm{pm}}$ & 0.89 & $4.4 \times 10^{4} \mathrm{~b}$ \\
6 & 40 & SYLD $=272.3+0.9\left(\mathrm{ET}_{\mathrm{n}}\right)_{\mathrm{ef}}+13.2\left(\mathrm{ET}_{\mathrm{n}}\right)_{\mathrm{fp}}+$ & 0.89 & \\
\hline
\end{tabular}

The error mean squares followed by the same letter within the same dependent variable are statistically insignificant at $5 \%$ level of probability. The $Z$-test statistics which follows a standard normal distribution was used to test the differences in error variances (Gupta and Kapoor, 1980).

TDM = total dry matter yield $\left(\mathrm{kg} \mathrm{ha}^{-1}\right) ; \mathrm{SYLD}=$ seed yield $\left(\mathrm{kg} \mathrm{ha}^{-1}\right) ; \mathrm{ET}=$ actual evapotranspiration $(\mathrm{mm}) ; \mathrm{ET}_{\mathrm{n}}=$ normalized evapotranspiration $\left(\mathrm{mm} \mathrm{kPa}^{-1}\right)$; ef $=$ emergence to $50 \%$ flowering; $\mathrm{fp}=50 \%$ flowering to $50 \%$ beginning pod-fill; $\mathrm{pm}=50 \%$ beginning pod-fill to physiological maturity; ep=emergence to $50 \%$ beginning pod-fill; $N=$ number of observations.

yield predictions could be based upon total normalized ET observed during the season.

As the number of pods and seeds are the major determinants of seed yield in chickpea (Singh and Auckland, 1975), the number of pods and seeds produced per unit area in different treatments were also regressed against total actual ET and normalized ET (Table 5). The results showed that the number of pods $\mathrm{m}^{-2}$ were more strongly correlated with normalized ET $\left(R^{2}=0.80\right)$ than with actual ET $\left(R^{2}=0.35\right)$. Like seed yield, further partitioning of ET into different growth phases did not improve the predictability of models. Similar results on the relation between seed numbers $\mathrm{m}^{-2}$ and ET were obtained as with the number of pods (Table 5).

To relate harvest index (HI) of chickpea with its pattern of water use, HI was regressed against ET during different periods of crop development and with fractional ET during the reproductive period (ratio of ET after flowering or after beginning pod-fill to total seasonal ET). Although the seed yield increased with the increase in $\mathrm{ET}, \mathrm{HI}$ had significant negative correlation with total seasonal ET $(r=-0.69, P<0.01)$ and with ET from $50 \%$ flowering to physiological maturity $(r=-0.44, P<0.01)$ (Table 6$)$. Total seasonal ET accounted for $49 \%$ of the variation in HI (Fig. 4). HI was not correlated with fractional ET after flowering or during the pod-filling period. These results 


\section{TABLE 5}

Equations relating pod number $\mathrm{m}^{-2}$ (number of pods) and seed number $\mathrm{m}^{-2}$ (no. of seeds) with normalized evapotranspiration; analysis done on 2 years pooled data

\begin{tabular}{|c|c|c|c|c|}
\hline $\begin{array}{l}\text { Equation } \\
\text { number }\end{array}$ & $N$ & Equation & $\begin{array}{l}\text { Adjusted } \\
R^{2}\end{array}$ & $\begin{array}{l}\text { Error mean } \\
\text { square }\end{array}$ \\
\hline & & Pod number $\mathrm{m}^{-2}$ & & \\
\hline 1 & 40 & No. of pods $=-230.3+5.2 \mathrm{ET}$ & 0.35 & $1.6 \times 10^{5} \mathrm{a}$ \\
\hline 2 & 40 & No. of pods $=-547.5+11.1 \mathrm{ET}_{\mathrm{n}}$ & 0.80 & $5.1 \times 10^{4} \mathrm{~b}$ \\
\hline 3 & 40 & No. of pods $=-417.5+7.6\left(E_{n}\right)_{e p}+15.5\left(E_{n}\right)_{p m}$ & 0.84 & $3.9 \times 10^{4} \mathrm{~b}$ \\
\hline 4 & 40 & $\begin{array}{l}\text { No. of pods }=-157.6+1.8\left(\mathrm{ET}_{\mathrm{n}}\right)_{\mathrm{ef}}+10.1\left(\mathrm{ET}_{\mathrm{n}}\right)_{\mathrm{fp}}+ \\
\quad 15.2\left(\mathrm{ET}_{\mathrm{n}}\right)_{\mathrm{pm}} \\
\text { Seed number m} \text { m }^{-2}\end{array}$ & 0.86 & $3.5 \times 10^{4} \mathrm{~b}$ \\
\hline 5 & 40 & No. of seeds $=-207.9+5.3 \mathrm{ET}$ & 0.35 & $1.7 \times 10^{5} \mathrm{a}$ \\
\hline 6 & 40 & No. of seeds $=-533.1+11.4 \mathrm{ET}_{\mathrm{n}}$ & 0.80 & $5.4 \times 10^{4} \mathrm{~b}$ \\
\hline 7 & 40 & No. of seeds $=-404.1+7.8\left(\mathrm{ET}_{\mathrm{n}}\right)_{\mathrm{ep}}+15.8\left(\mathrm{ET}_{\mathrm{n}}\right)_{\mathrm{pm}}$ & 0.84 & $4.1 \times 10^{4} \mathrm{~b}$ \\
\hline 8 & 40 & $\begin{array}{l}\text { No. of seeds }=-119.0+1.5\left(\mathrm{ET}_{\mathrm{n}}\right)_{\mathrm{ef}}+10.6\left(\mathrm{ET}_{\mathrm{n}}\right)_{\mathrm{fp}}+ \\
\quad 15.5\left(\mathrm{ET}_{\mathrm{n}}\right)_{\mathrm{pm}}\end{array}$ & 0.86 & $3.7 \times 10^{4} \mathrm{~b}$ \\
\hline
\end{tabular}

The error mean squares followed by the same letter within the same dependent variable are statistically insignificant at $5 \%$ level of probability. The $Z$-test statistics which follows a standard normal distribution was used to test the differences in error variances (Gupta and Kapoor, 1980).

Note: for description of independent variables and subscripts see Table 4.

TABLE 6

Correlation of HI of chickpea with ET during different growth periods

\begin{tabular}{lllllll}
\hline Season & $N$ & $\mathrm{ET}_{\mathrm{fm}}$ & $\mathrm{ET}_{\mathrm{pm}}$ & $\mathrm{ET}_{\mathrm{em}}$ & $\mathrm{ET}_{\mathrm{fm}} / \mathrm{ET}_{\mathrm{em}}$ & $\mathrm{ET}_{\mathrm{pm}} / \mathrm{ET}_{\mathrm{em}}$ \\
\hline & Correlation coefficients $(r)$ & & \\
1986 & 20 & $-0.73^{* *}$ & -0.23 & $-0.78^{* *}$ & $-0.53^{*}$ & -0.17 \\
1987 & 20 & $-0.56^{* *}$ & -0.43 & $-0.67^{* *}$ & -0.22 & -0.11 \\
Pooled & 40 & $-0.44^{* *}$ & -0.12 & $-0.69^{* *}$ & -0.08 & -0.20 \\
\hline
\end{tabular}

*, ** represent significance at $5 \%$ and $1 \%$ level of probability, respectively.

$\mathrm{ET}_{\mathrm{fm}}=\mathrm{ET}$ from $50 \%$ flowering to maturity; $\mathrm{ET}_{\mathrm{pm}}=\mathrm{ET}$ from $50 \%$ beginning pod-fill to maturity; $\mathrm{ET}_{\mathrm{em}}=\mathrm{ET}$ from emergence to maturity.

are in contrast to those observed for determinate crops. For example, Passioura (1977) reported that $\mathrm{HI}$ of wheat was directly proportional to the per cent water used after anthesis. As the fallen leaves were collected in each treatment of this study to determine total biomass production, the increase in HI of chickpea under water stress could be attributed to its physiological adaptation to water stress resulting in less vegetative growth and hastening of 


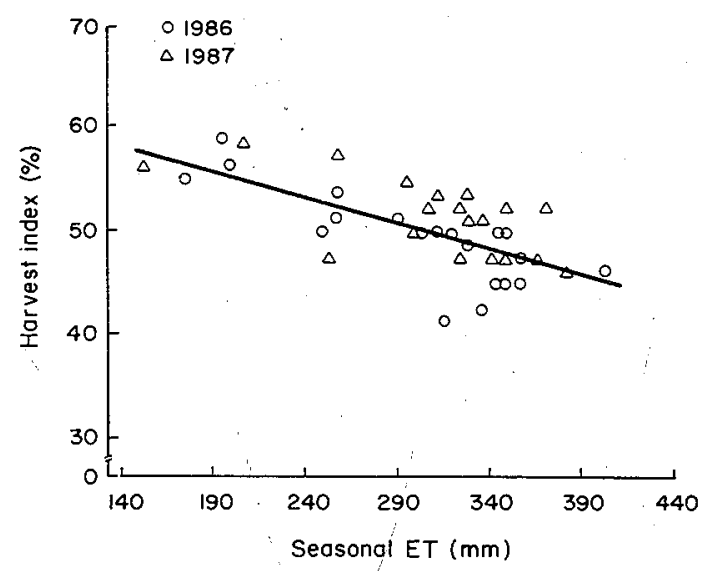

Fig. 4. Relation of harvest index of chickpea with total seasonal ET ( $Y=65.5-0.05 X$, rse $=3.06$, $R^{2}=0.47, P<0.01$ ) for the 2-year pooled data:

phenological development (Saxena, 1984) and presumably because of greater allocation of assimilates to root relative to shoot.

\section{CONCLUSIONS}

It is concluded from this study that normalized ET is more closely related to both total above ground dry matter production $\left(R^{2}=0.92, P<0.01\right)$ and seed yield $\left(R^{2}=0.82, P<0.01\right)$ of chickpea than actual ET. Although the seed yield of chickpea increased with the increase in ET, HI was negatively related to total seasonal ET and ET from flowering to physiological maturity, which could be attributed to its physiological adaptation to water stress. We conclude from this study that chickpea biomass and seed yield responses to soil water availability and supplemental irrigation could be estimated using the regression equations relating chickpea yield with normalized ET observed during the season.

\section{ACKNOWLEDGMENTS}

The authors thank S. Ramakrishna, R. Mukunda Reddy, and P.V.V. Satyanarayana for their assistance in the field and K.P.C.S. Raju for typing the manuscript.

\section{REFERENCES}

Aujla, T.S. and Cheema, S.S., 1985. Water use, root density and yield of chickpea (Cicer arietinum) as affected by levels of soil-moisture storage with and without post-sowing irrigations. Indian J. Ecol., 12: 91-98. 
Bierhuizen, J.F. and Slatyer, R.O., 1965. Effect of atmospheric concentration of water vapour and $\mathrm{CO}_{2}$ in determining transpiration-photosynthesis relationships of cotton leaves. Agric. Meteorol., 2: 259-270.

Gupta, S.C. and Kapoor, V.K., 1980. Fundamentals of Mathematical Statistics (7th Edn.). Sultan Chand, New Delhi, pp. 677-678.

Hanks, R.J., Keller, J., Rasmussen, V.P. and Wilson, G.D., 1976. Line-source sprinkler for continuous variable irrigation in crop production studies. Soil Sci. Soc. Am. J., 40: 426-429.

Keatinge, J.D.H. and Cooper, P.J.M., 1983. Kabuli chickpea as a winter-sown crop in northern Syria: moisture relations and crop productivity. J. Agric. Sci. Camb., 100: 667-680.

Passioura, J.P., 1977. Grain yield, harvest index, and water use of wheat. J. Aust. Inst. Agric. Sci., 43: 117-120.

Ritchie, J.T., 1972. Model for predicting evaporation from a row crop with incomplete cover. Water Resources Res., 8: 1204-1213.

Sandhu, B.S., Prihar, S.S., Khera, K.L. and Sandhu, K.S., 1978. Scheduling irrigation to chickpea. Indian J. Agric. Sci., 48: 486-492.

Saxena, N.P., 1984. Chickpea. In: P.R. Goldsworthy and N.M. Fisher (Editors), The Physiology of Tropical Field Crops. Wiley, Chichester, pp. 419-452.

Sheldrake, R. and Saxena, N.P., 1979. Growth and development of chickpeas under progressive moisture stress. In: H. Mussell and R.C. Staples (Editors), Stress Physiology in Crop Plants. Wiley, New York, pp. 465-483.

Siddique, K.H.M. and Sedgley, R.H., 1985. The effect of reduced branching on yield and water use of chickpea (Cicer arietinum $\mathbf{L}$.) in a Mediterranean type environment. Field Crops Res., 12: 251-269.

Singh, D.P., Rawson, M.M. and Turner, N.C., 1982. Effect of radiation, temperature and humidity on photosynthesis, transpiration and water use efficiency of chickpea (Cicer arietinum L. ). Indian J. Plant Physiol., 25: 32-39.

Singh, G. and Bhushan, L.S., 1980. Water use, water-use efficiency and yield of dryland chickpea as influenced by $P$ fertilization, stored soil water and crop season rainfall. Agric. Water Manage., 2: 299-305.

Singh, K.B. and Auckland, A.K., 1975. Chickpea breeding at ICRISAT. In: Proceedings of the International Workshop on Grain Legumes, 13-16 January 1975, Hyderabad, A.P., India, pp. 3-17.

Singh, P. and Sri Rama, Y.V., 1989. Influence of water deficit on transpiration and radiation use efficiency of chickpea (Cicer arietinum L.). Agric. For. Meteorol., 48: 317-330.

Singh, R.P. and Das, S.K., 1987. Management of chickpea and pigeonpea under stress conditions with particular reference to drought. In: Adaptation of Chickpea and Pigeonpea to Abiotic Stresses. Proc. Consultants' Workshop, 19-21 December, 1984, ICRISAT Center, India, pp. 51-61.

Sivakumar, M.V.K. and Singh, P., 1987. Response of chickpea cultivars to water stress in a semi-arid environment. Expl. Agric., 23: 53-61.

Tanner, C.B. and Sinclair, T.R., 1983. Efficient water use in crop production: research or research. In: H.M. Taylor, R.W. Jordan and T.R. Sinclair (Editors), Limitations to Efficient Water Use in Crop Production. Am. Soc. Agron., Madison, WI, pp. 1-28. 